\title{
PROBLEMS OF IMPLEMENTATION OF ERGODESIGN TECHNOLOGIES IN EDUCATIONAL INSTITUTIONS
}

\section{ПРОБЛЕМИ РЕАЛІЗАЦІЇ ТЕХНОЛОГІЙ ЕРГОДИЗАЙНУ В ЗАКЛАДАХ ОСВІТИ}

\author{
Tetyana BORISOVA, \\ Candidate of Pedagogical \\ Sciences, Associate Professor \\ Poltava V.G. Korolenko National \\ Pedagogical University \\ 2 OstrogradskySt., \\ Poltava, Poltava region, 36000
}

borisova.tanya@ukr.net
Тетяна БОРИСОВА,

кандидат педагогічних наук, доцент

Original manuscript received: October 11, 2019

Revised manuscript accepted: December 21, 2019

\begin{abstract}
In accordance with the requirements of today, the development of new and modernization of existing products should be carried out taking into account the latest achievements of ergonomics and design, at the same time, ergodesigner indicators of the product become one of the main in assessing the consumer quality of products. Possession of tools of ergodesign creates favorable conditions for improvement of structure and a form of objects of project, and promotes increase of their consumer properties.

Ergodesign technologies are based on two components. The ergonomic component of the ergodesign category reveals the principles of optimization of conditions and means of human activity in accordance with the law of conformity and the theory of functional comfort. The design component of this category is based on the principles of project and technological culture and defines the project activities aimed at creating the object environment according to the laws of composition, in particular, objects with high consumer properties, an appropriate level of aesthetic and functional perfection, as well as ergonomics. The combination of scientific directions acmeological and ergonomic-in the complex of technologies of ergodesign creates favorable conditions for the successful implementation of the principle of integration of science and education, as well as provides a solution to a certain range of problems for both educational and industrial practice.

The complex of ergodesign technologies contributes to the formation of a special subject worldview, develops a person's own worldview, reflecting a holistic vision of the environment. The introduction of the basics of ergodesign in every educational process, which is aimed at productive activities and the result of which is the material embodiment of the idea is an important vector of development of professional and technological education. The problem of designing a complex system of technologies of ergodesign directly associated with the provision of a holistic artistic
\end{abstract}


Серія: Педагогічні науки. - Вип.3. - Бердянськ : БДПУ, 2019. - 453 с.

and aesthetic and project-technological preparation of youth to the implementation of the highly competitive professional activities aimed at the development and manufacture of comfortable and at the same time functionally effective design objects.

Development and substantiation of new principles and methods of learning with engaging ergodesign technologies will provide future professionals with the knowledge, skills and abilities necessary for self-realization and competitiveness.

Key words: design-education, ergodesign, training of technologies of ergodesign, training of specialists in ergodesign, professional qualities of specialists in ergodesign.

Вступ. Зміни, що намітилися нині в системі освіти в цілому, не оминають і дизайнерську, і ергономічну підготовку фахівців. Дизайносвіта в сучасних умовах повинна бути спрямована на підготовку, підвищення кваліфікації та перепідготовку фахівців нової формації, які здатні враховувати різні аспекти проектної діяльності, зокрема ергономічні показники якості виробів.

Дизайн-освіта як окремий базовий рівень не може належним чином задовольняти нові вимоги, які висуває сучасна ринкова економіка. Навчальні програми більшістю зорієнтовані на художньо-естетичну складову дизайн-проєктування, в них переважно не приділяється належної уваги ергономічній складовій. Феномен людини, як об'єкта та суб'єкта дизайнерської діяльності, а особливо як користувача результатами дизайн-проєктування у змісті навчальних програм розглядається фрагментарно. У процесі навчання не висвітлюються проблеми особистісно-професійного розвитку фахівців з ергодизайну, формування позитивної мотивації до праці, здатності до саморозвитку.

У новій економічній ситуації необхідні професіонали у сфері ергодизайну інноваційної формації, здатні забезпечувати споживчі переваги виробів, ураховувати фактор кон'юнктури ринку, вести розробку від первинних ідей до виведення продукції на ринок товарів високої якості, співпрацювати з усіма фахівцями, від яких залежить конкурентоспроможність виробів на споживчому ринку (технологами, фрінансистами, менеджерами, маркетологами, спеціалістами з якості та іншими фахівцями). Вітчизняна дизайнерська школа з її давніми традиціями гуманістичної культури як основи дизайнерського світобачення потребує сьогодні переходу до такої форми освіти, яка ґрунтується на сучасних економічних, виробничих, технологічних знаннях, проблемах і ситуаціях.

Дієвим способом підвищення рівня професіоналізму фрахів 3 ергодизайну в різних галузях $є$ створення сучасної ефективної системи безперервної освіти. Вона має бути гнучкою і більш чутливою до потреб суспільства, що розвивається, а також окремої людини. Така система дозволяє підняти конкурентоспроможність фахівця за рахунок особистісного саморозвитку, поглиблення професійних знань і розширення спектра професійних можливостей.

Важливою ланкою системи дизайн-освіти $€$ введення основ дизайну та ергономіки як цілісного освітнього компонента на всіх рівнях професійної підготовки, спрямов на періодичне оновлення професійних 
знань, вдосконалення професійної майстерності фахівців, їх особистісний розвиток.

Уперше ергодизайн ретельно був розглянутий як проєктна стратегія нового зразка А. Вассерманом на початку $80-x$ років XX століття. Питання теоретичного обґрунтування ергодизайну як наукового напряму розробляли
Т. Богатирьова,
А. Буров,
В. Даниляк,
В. Зінченко,
Ю. Манусевич,

В. Муніпов, Л. Ремізовський,

В. Рунге. Проблеми впровадження основ ергодизайну в освітню практику розглядали О. Бойчук, В. Голобородько, В. Прусак, А. Рубцов, В. Свірко, Л. Чайнова, Е. Яблокова. Але, незважаючи на спроби поширити ергодизайнерську підготовку серед фрахівців різних спеціальностей, потребує комплексного дослідження проблема реалізації технологій ергодизайну в закладах освіти.

Мета статті - окреслити коло проблем та визначити перспективні напрями реалізації технологій ергодизайну в закладах освіти.

Методи та методики дослідження. Для проведення ґрунтовного дослідження напрямів реалізації технологій ергодизайну в закладах освіти здійснено теоретичний аналіз феномену ергодизайну та визначено критерії розвитку ергодизайн-освіти. Для досягнення поставленої мети використовувалися теоретичні методи наукового пошуку (аналіз науковопедагогічних та методичних праць, синтез складових освітніх процесів, узагальнення педагогічного досвіду, пояснення взаємозв'язків між складовими цілісного процесу, класифікація). Узагальнення i систематизація теоретико-методологічних підходів до визначення ергодизайну як наукового напряму дозволили окреслити особливості поширення ергономічної та дизайнерської підготовки в закладах освіти.

Результати та дискусії. Ергодизайн спрямований на проєктування складних технічних об'єктів, засобів праці і в цілому предметного світу людини з високими естетичними властивостями, що задовольняють безперервне зростання і мінливі потреби сучасності, а також на забезпечення безпечної та комфортної діяльності людини 3 різними об'єктами та системами предметного світу, при проєктуванні яких ураховуються індивідуальні особливості та фрізіологічні можливості.

Ергодизайн виник на зрізі двох наукових напрямів як симбіоз ергономіки та дизайну, поєднавши в собі сучасні технології проектування, відмінні від суто технічного та художнього проектування. Ергодизайн - це комплекс сучасних прогресивних технологій, спрямованих на проєктування та виготовлення якісної, технічно й естетично досконалої конкурентоспроможної продукції. Реалізація такого комплексу можлива лише за умови вдалого поєднання діяльності дизайн-проектування та ергономічного аналізу. Спільна діяльність дизайнерів та ергономістів на всіх етапах виробництва продукції найбільш повно реалізує відповідність об'єктів проєктування умовам їх використання людиною. Отже, під ергодизайном розуміють людиноорієнтоване проектування техніки, програмованих засобів і предметного середовища (Зинченко, 2001). Проєктування такої спрямованості забезпечує естетичну складову при наявності зручності у використанні й забезпеченні комфортних умов функціонування. При цьому 
Серія: Педагогічні науки. - Вип.3. - Бердянськ : БДПУ, 2019. - 453 с.

на першому місці знаходиться людина як об'єкт роботи будь-якої системи, а на другому - предмет, яким вона оперує, з його досконалими естетичними та функціональними характеристиками.

Естетичні властивості виробів, побудовані за законами композиції, створюють привабливий товарний вигляд та впливають на конкурентоспроможність продукції. Дійсно, спершу людина звертає увагу на красивий зовнішній вигляд виробу. Але поряд з красою не менш важливим аспектом популярності виробу на ринку товарів $\epsilon$ його функціональність, надійність та зручність.

Упровадження технологій ергодизайну в освітній процес передбачає реалізацію двох складових цієї науки - ергономічної та дизайнерської. Для успішного поєднання дизайну та ергономіки у виробничих умовах необхідне усвідомлення єдності краси та функціональності фахівцями з ергодизайну на підготовчих етапах, тобто ще під час навчання. Звичайно, навчання технологій ергодизайну повинно відбуватися на рівні підготовки фахівців проєктно-технологічного напряму в кожній галузі виробництва. Та не менш важливим фактором $є$ поширення основ ергодизайну в кожний освітній процес, спрямований на продуктивну діяльність, результатом якої є матеріальне втілення задуму.

Залучення до проєктно-технологічної діяльності майбутніх фахівців 3 ергодизайну відбувається 3 урахуванням інтересів, культури саморозвитку і самореалізації, передбачає не тільки синтез ергономіки та дизайну, але вимагає широкого виконання можливостей акмеологічної науки, що досліджує закономірності та механізми досягнення людиною професійного та особистісного “акме”, становлення як активного творчого суб'єкта соціальної практики і власної долі, що розглядає особистісну і професійну зрілість як вищі форми соціалізації людини (Задесенець, 2007).

Процес модернізації освіти передбачає освоєння новітніх освітніх концепцій і технологій. Акмеологічний аспект у системі дизайн-освіти в поєднанні з концепцією ергодизайнерської підготовки як інноваційної людиноорієнтованої технології, на думку науковців, може стати тим прогресивним засобом, здатним позитивно впливати на процес модернізації професійної підготовки майбутніх фахівців у сфрері ергодизайну. До цього варто додати, що об'єднання наукових напрямів акмеологічного та ергономічного - у комплекс технологій ергодизайну створює сприятливі умови для успішної реалізації принципу інтеграції науки й освіти, а також забезпечує вирішення певного кола завдань як для освітньої, так і виробничої практики.

На сучасному етапі розвитку науки та технологій значення ергодизайну набуває все більшої значимості, адже різко підвищилися вимоги безпеки та комфорту до результатів проєктно-технологічної діяльності. Однак ще наприкінці минулого століття окремо функціонували як дизайнерські, так і ергономічні технології, тільки рівень їх реалізації в проєктній діяльності був різним. У той період дизайн-проєкти створювалися, як правило, самостійно і реалізовувалися незалежно. До ергономістів зверталися лише у випадках виявлення недоліків, 
пов'язаних з нехтуванням ергономічних вимог, і переважно у тому разі, коли виріб запустили у виробництво, а недоліки виявлялися при його експлуатації людиною. Робота ергономістів полягала в проведенні ерономічного аналізу вже готового виробу з метою надання рекомендацій щодо усунення виявлених недоліків. Адміністративний тиск на розвиток дизайну та виробничих процесів у XX столітті стримував і розвиток ергономіки, тому вона виконувала функцію переважно коригуючої науки.

Однак звернення до даних ергономічних досліджень лише на етапі експлуатації продукції не задовольняє нові умови господарювання, де конкурентоспроможність товарів цілком залежить від їх якості. Стало очевидним, що в умовах ринкової економіки за відсутності дефіциту промислової продукції увагу сучасного користувача привертають тільки ті вироби, які відповідають його потребам, запитам і очікуванням. При цьому користувач може отримати задоволення в разі естетичної досконалості виробу та зручності його експлуатації.

Bce більше утверджується нова форма використання знань ергономіки, при якій може бути забезпечено найвищий результат у реалізації продукції за рахунок її конкурентоспроможності як на внутрішньому, так і зовнішньому ринках. I в цій ситуації втручання ергономіста в процес дизайнпроєктування має відбуватися якомога раніше, тобто на початкових стадіях проєктування, щоб максимально врахувати вимоги ергономіки при створенні різних об'єктів (Голобородько, 2013). Саме такий підхід до проєктування промислових та інших виробів привів до появи нового виду науковопроєктної діяльності, що отримав назву “ергодизайн”.

Серед наукових та освітніх установ, що на державному рівні вирішують питання координації сфери дизайну та ергономіки, чільне місце займає Український науково-дослідний інститут дизайну та ергономіки. Його діяльність УкрНДІ спрямована на формування в Україні інноваційної, здатної до саморозвитку системи дизайн-ергономічного забезпечення промислового комплексу, формування повноцінного середовища життєдіяльності людини. Дослідження інституту орієнтовані на розв'язання завдань забезпечення економічної доцільності та ефективності промислового товарного виробництва, створення сучасного предметного середовища життєдіяльності людини методами дизайну та ергономіки. Важливим напрямком діяльності інституту є дизайн-ергономічне проєктування промислових виробів.

УкрНДІ дизайну та ергономіки здійснює ряд ініціативних розробок щодо підготовки та перепідготовки фахівців у галузі дизайну; розробляє документацію з акредитації організацій та фізичних осіб, зайнятих у галузі дизайну та ергономіки. Перспективним напрямом діяльності інституту $\epsilon$ робота з підвищення кваліфікації, перепідготовки дизайнерів та ергономістівпрактиків. Підготовка фахівців з ергодизайну спирається як на реалізацію проєктної думки, так і на світовідчуття і самосвідомість молодих фахівців. Сучасні підходи до проблеми оновлення та вдосконалення системи ергодизайнерської підготовки дозволяє визначити необхідні професійно значущі якості фахівців-дизайнерів нового покоління. До них відносяться: здатність брати участь у створенні високоякісної наукомісткої продукції, 
забезпечувати просування науково-технічних досягнень у виробництво та на ринки збуту; готовність орієнтуватися на соціально-економічні зміни, що відбуваються в суспільстві; усвідомлення важливості своєї професійної діяльності в суспільстві як гарантів проєктування досконалого гуманізованого предметного оточення; вміння успішно використовувати у своїй професійній діяльності вітчизняні та зарубіжні науково-технічні досягнення; володіння знаннями в області інформаційних і людиноорієнтованих технологій, здатність до їх застосування у своїй практиці; зацікавленість у професійному зростанні; знання основ менеджменту та вміння їх реалізувати при організаційному проєктуванні й управлінні інноваційним процесом; володіння функціями маркетолога і можливість їх застосування при проєктному моделюванні інноваційного процесу як ринкової операції.

Ураховуючи вищеозначені вимоги до фахівців нового покоління в галузі ергодизайну, варто звернути увагу на розробку нової концепції якісної освіти в сорері ергодизайну та принципи її реалізації. Вона буде орієнтована на підготовку кваліфікованих фахівців нового покоління, конкурентоспроможних на ринку праці, що відповідають вимогам професійної дизайнерської діяльності з урахуванням вимог ергономіки в умовах ринкової економіки і в новій конкурентній внутрішньо-професійній сфрері. Вона забезпечить слухачів сучасними знаннями в області ергодизайну та суміжних сферах діяльності, сприятиме формуванню навичок використання отриманих знань безпосередньо в професійній дизайнерській діяльності. Однак отримання певної суми знань не гарантує фрормування професіонала високого рівня, здатного до ефективної роботи за фахом на рівні світових стандартів. Пропонована концепція освіти передбачає особистісно-професійний розвиток фахівця шляхом підвищення рівня позитивної мотивації до праці, формування здібностей до самоосвіти, саморозвитку, підвищенню рівня самооцінки і конкурентоспроможності фахівця. Самореалізація креативної особистості може стати запорукою розвитку гармонійного суспільства.

Інноваційний підхід до освітнього процесу у сфері ергодизайну передбачає не просто механічне поєднання досягнень ергономіки, дизайну і акмеології, але забезпечує синтез, інтеграцію отриманих у кожній з цих наук результатів. Такий синтез має вагоме підґрунтя. Кожна з названих наук своєрідно розробляє творчий підхід стосовно різних сфер суспільної практики та індивідуального життя людини. Організація цих сфер передбачає пошук шляхів оптимального поєднання громадського та індивідуального, людини і середовища, гармонізацію предметного і духовного компонентів, в кінцевому результаті - досягнення високої якості життя людини і суспільства, одним з базових підстав якого може і повинна стати гуманістична спрямованість кожної з сфер життєдіяльності людини як індивіда, особистості, суб'єкта (Свірко, 2011).

Розробка освітніх програм з ергодизайну повинна базуватися на певних критеріях, серед них виділяємо, по-перше, потребу суспільства в підготовці та перепідготовці кадрів, які працюють у сфері дизайну та ергономіки або здійснюють іншу проєктно-технологічну діяльність; по-друге, 
необхідність освоєння фахівцями основ ергодизайну; по-третє, оволодіння знаннями і навичками інноваційного дизайну, в тому числі синтезу дизайну і ергодизайн, теорії проєктної культури та методології дизайн-проєктування за допомогою комп'ютерних технологій; по-четверте, психологічне забезпечення профресійної діяльності та особистісного розвитку фахівцядизайнера, урахування людського фрактора в управлінні якістю, підвищення конкурентоспроможності продукції, по-п'яте, вміння фрахівців з ергодизайну орієнтуватися в соціальному контексті сучасного суспільства, макро- і мікроекономіці, менеджменті та маркетингу. Дотримання означених критеріїв дозволить підібрати комплекс навчальних дисциплін, спрямованих не лише на вдосконалення світу речей, предметного середовища буття людини, а особистісний розвиток фахівців з егодизайну, формування власної культури і культури відносин з іншими людьми.

Вдало підібраний комплекс навчальних дисциплін сприяє повноцінному формуванню професійно-значимих знань, умінь та навичок для майбутньої проєктної діяльності. У результаті навчання майбутні фрахівці з ергодизайну отримують цілісне уявлення про дизайн і сучасні методи комп'ютерного проєктування; вивчають основні поняття та напрями ергономіки, її місце в проєктуванні, методах використання ергономічних знань в процесі створення предметного середовища людини в різних видах діяльності; набувають психологічні та антропометричні знання, необхідні при проєктуванні предметного світу, а також навички професійного спілкування та профеесійної етики; вивчають проблеми управління якістю промислових виробів і освоєння нової продукції споживачами; освоюють економічні і правові знання, необхідні в дизайнерської діяльності в умовах ринкових відносин.

Висновки. Знання основ ергодизайну як базової складової організації життєдіяльності людини потрібні фахівцям різних напрямів діяльності. Поєднання естетики та комфорту повинно стати цілісним компонентом будь-якої проєктної діяльності. Фахова майстерність фахівців 3 ергодизайну $€$ запорукою ефективного проєктування комфортного предметного середовища. А відтак, упровадження технологій ергодизайну у процес підготовки фрахівців певної галузі дизайн-проєктування, а їх розмаїття досить широке, потребує окремого вивчення та розробки комплексних рекомендацій щодо їх впровадження.

\section{Література}

1. Голобородько В. М. Ергодизайн як методологічна стратегія сучасної дизайн-ергономічної діяльності / Голобородько В.М., Свирко В.О., Рубцов А.Л. // Вісник Харківсьої державної академії дизайну і мистецтв - 2013. - № 2. - С. 23-26.

2. Задесенец Е. Е. Акмеологический подход к подготовке специалистов в области эргодизайна через систему дополнительного образования / Задесенец Е.Е., Чайнова Л.Д., Яблокова Е.А. // Акмеология. - 2007. - № 1.

3. Зинченко В. П. Эргономика: человекоориентированное проектирование техники, программных средств и среды : учебник / В. П. Зинченко, В. М. Мунипов. - М. : Логос, 2001. -356 c.

4. Свірко В. О. Основи ергодизайну : навчальний посібник / Свірко В.О., Бойчук О.В., Голобородько В.М., Рубцов А.Л. / МСН МС України; Український науково-дослідний інститут дизайну та ергономіки. - Київ : НАУ, 2011. - 300 с. 


\section{References}

1. Holoborodko V.M., Svyrko V.O., Rubtsov A.L. (2013). Erhodyzain yak metodolohichna stratehiia suchasnoi dyzain-erhonomichnoi diialnosti [Ergodesign as a Methodological Strategy of Modern Design-ergonomic Activity], (pp.23-26). Kharkiv : Visnyk Kharkivsoi derzhavnoi akademii dyzainu i mystetstv - № 2 [in Ukrainian].

2. Zadesenets E.E., Chainova L.D., Yablokova E.A. (2007). Akmeolohycheskyi podkhod k podhotovke spetsyalystov $v$ oblasty erhodyzaina cherez systemu dopolnytelnoho obrazovanyia [Acmeological Approach to the Training of Specialists in the Field of Ergodesign through the System of Additional Education], Akmeolohyia - № 1 [in Ukrainian].

3. Zynchenko V.P., Munypov V.M. (2001). Erhonomyka: chelovekooryentyrovannoe proektyrovanye tekhnyky, prohrammnykh sredstv i sredy: uchebnyk [Ergonomics: Human-Oriented Design of Technology, Software, and Environment: a textbook]. Moskva : Lohos [in Russian].

4. SvirkoV.O., Boichuk O.V., Holoborodko V.M., Rubtsov A.L. (2011). Osnovy erhodyzainu : navchalnyi posibnyk [Basics of Ergodesign: a textbook], MSN MS Ukrainy; Ukrainskyi naukovo-doslidnyi instytut dyzainu ta erhonomiky. Kyiv : NAU [in Ukrainian].

\section{АНОТАЦІЯ}

Відповідно до вимог сьогодення розробка нових та модернізація наявних виробів повинна здійснюватися з урахуванням новітніх досягнень ергономіки $i$ дизайну. При цьому ергодизайнерські показники виробу стають одними 3 головних при оцінці споживчих якостей продукції. Володіння інструментарієм ергодизайну створює сприятливі умови вдосконалення структури та форми об'єктів проєктування, а також сприяє підвищенню їх споживчих властивостей.

Технології ергодизайну базуються на двох складових. Ергономічна складова категорії ергодизайну розкриває принципи оптимізації умов та засобів діяльності людини відповідно до закону відповідності та теорії функціонального комфорту. Дизайнерська складова категорії ергодизайну спирається на принципи проєктно-технологічної культури й визначає проєктну діяльність, спрямовану на створення предметного середовища за законами композиції, зокрема, об'єктів з високими споживчими властивостями, належним рівнем естетичної та фуннкціональної досконалості, а також ергономічності.

Комплекс технологій ергодизайну сприяє фрормуванню особливого предметного світобачення, розвиває власний світогляд людини, що відображає иілісне сприйняття навколишнього середовища. Упровадження основ ергодизайну в кожний освітній процес спрямовано на продуктивну діяльність, результатом якого $\epsilon$ матеріальне втілення задуму - важливий вектор розвитку професійної та технологічної освіти. Проблема проєктування комплексної системи технологій ергодизайну безпосередньо пов'язана із забезпеченням иілісної художньо-естетичної та проектно-технологічної підготовки молоді до здійснення висококонкурентної профресійної діяльності, спрямованої на розробку та виготовлення зручних і водночас фуннкціонально ефрективних дизайн-об’єктів. Розробка та обгрунтування нових принципів і методів навчання із залученням технологій ергодизайну забезпечать майбутніх фрахівців знаннями, уміннями та навичками, необхідними для самореалізації й конкурентоздатності.

Ключові слова: дизайн-освіта, ергодизайн, навчання технологій ергодизайну, підготовка фрахівців з ергодизайну, професійні якості фрахівців $з$ ергодизайну. 